\title{
Manipulating Globalization
}




\section{APARC}

\section{ASIA-PACIFIC RESEARCH CENTER}

Studies of the Walter H. Shorenstein Asia-Pacific Research Center

Andrew G. Walder, General Editor

The Walter H. Shorenstein Asia-Pacific Research Center in the Freeman Spogli Institute for International Studies at Stanford University sponsors interdisciplinary research on the politics, economies, and societies of contemporary Asia. This monograph series features academic and policyoriented research by Stanford faculty and other scholars associated with the Center. 


\section{Manipulating Globalization}

THE INFLUENCE OF BUREAUCRATS

ON B USINESS IN C H I A

Ling Chen

Stanford University Press

Stanford, California 
Stanford University Press

Stanford, California

(C) 2018 by the Board of Trustees of the Leland Stanford Junior University. All rights reserved.

No part of this book may be reproduced or transmitted in any form or by any means, electronic or mechanical, including photocopying and recording, or in any information storage or retrieval system without the prior written permission of Stanford University Press.

Printed in the United States of America on acid-free, archival-quality paper

Library of Congress Cataloging-in-Publication Data

Names: Chen, Ling, I98-author.

Title: Manipulating globalization : the influence of bureaucrats on business in China / Ling Chen.

Other titles: Studies of the Walter H. Shorenstein Asia-Pacific Research Center.

Description: Stanford, California : Stanford University Press, 2018. | Series:

Studies of the Walter H. Shorenstein Asia-Pacific Research Center | Includes bibliographical references and index.

Identifiers: LCCN 2017038610 | ISBN 9781503604797 (cloth : alk. paper) | ISBN 978I 503605695 (epub)

Subjects: LCSH: China-Economic policy-200o- | Industrial policy-China. |

Local government-China. | Bureaucracy-Economic aspects-China. |

Globalization-Economic aspects-China.

Classification: LCC HC427.95 .C4334I 42018 | DDC 338.095 I-dc23

LC record available at https://lccn.loc.gov/2017038610

Typeset by Thompson Type in II/I4 Adobe Garamond 
For Sophie 
This page intentionally left blank 